\title{
The Potential Use of Entomopathogenic Nematodes to Control Planococcus ficus (Signoret) (Hemiptera: Pseudococcidae)
}

\author{
P.D. le Vieux* and A.P. Malan
}

Department of Conservation Ecology and Entomology, Stellenbosch University, Stellenbosch, South Africa

Submitted for publication: June 2013

Accepted for publication: August 2013

Key words: Bioassays, Heterorhabditidae, Heterorhabditis zealandica, insect parasitic nematodes, vine mealybug, Steinernematidae, Steinernema yirgalemense

\begin{abstract}
Laboratory bioassays were conducted to establish the potential of entomopathogenic nematodes (EPNs) as biocontrol agents of Planococcus ficus (Signoret). Six indigenous and two commercially available nematode species were screened for their efficacy in killing adult female $P$. ficus. The two indigenous species with the most promising results were Heterorhabditis zealandica and Steinernema yirgalemense, which were responsible for $96 \%$ and $65 \%$ mortality respectively. Tests were conducted to compare the efficacy of H. bacteriophora and $S$. feltiae produced in vivo and in vitro. Heterorhabditis bacteriophora showed no significant difference in efficacy between the two production methods, but in vivo-cultured $S$. feltiae produced a significantly higher mean mortality of $40 \%$, in contrast to a $19 \%$ mean mortality with in vitroproduced infective juveniles (IJs). The capability of both $\boldsymbol{H}$. zealandica and $S$. yirgalemense to complete their life cycles in the host and to produce a new cohort of IJs was demonstrated. Bioassays indicated a concentration-dependent susceptibility of $P$. ficus to $H$. zealandica, $S$. yirgalemense and commercially produced $H$. bacteriophora, with $\mathrm{LC}_{50}$ and $\mathrm{LC}_{90}$ values of 19, 82; 13, 80; and 36, 555 respectively. Both $H$. zealandica and $S$. yirgalemense were able to move $15 \mathrm{~cm}$ vertically downward and infect $P$. ficus with a respective mortality of $82 \%$ and $95 \%$. This study showed $P$. ficus to be a suitable host for $\boldsymbol{H}$. zealandica and $S$. yirgalemense, with both nematode species showing considerable potential for future use in the field control of $P$. ficus.
\end{abstract}

\section{INTRODUCTION}

Mealybugs (Pseudococcidae) are severe agricultural pests that pose major problems for farmers (Miller et al., 2002). The vine mealybug, Planococcus ficus (Signoret), has been shown to be the dominant mealybug species in South African vineyards (Kriegler, 1954; Walton, 2003), and is characteristically more economically damaging than any other mealybug species found on vines (Haviland et al., 2005; Daane et al., 2008).

Compared to Pseudococcus maritimus (Ehrhorn), Pseudococcus longispinus (Targioni-Tozzetti) and Pseudococcus viburni (Signoret), P. ficus excrete more honeydew per individual, have both a faster development time and a higher reproductive rate of more than 250 eggs per female, and are able to feed on all parts of the vine throughout the year (Daane et al., 2003, 2008; Haviland et al., 2005). Planococcus ficus is a vector for Shiraz disease, corky bark disease and the grapevine leafroll-associated virus 3 (GLRaV-3), making it a potential economic threat even at low densities (Walton \& Pringle, 2004b; Douglas \& Kruger, 2008; Holm, 2008). Mealybugs are difficult to control with chemicals due to their cryptic lifestyles of hiding in crevices, under bark and below ground on roots, where they are protected from insecticidal sprays (Walton $\&$ Pringle, 2004b). Their hydrophobic waxy secretions repel water-based insecticides, and they have the ability to develop resistance rapidly (Flaherty et al., 1982; Walton \& Pringle, 2004b; Franco et al., 2009). There thus is a need for new and improved $P$. ficus control options.

Entomopathogenic nematodes (EPNs) of the Heterorhabditidae and Steinernematidae families occur in soils in most parts of the globe, and are deadly parasites to a wide range of insects (Stuart et al., 1997). Heterorhabditidae and Steinernematidae have a unique symbiotic association with the entomopathogenic bacteria genera Photorhabdus and Xenorhabdus respectively, and together they effectively parasitise and kill their insect hosts (Ehlers, 2001). When encountering a suitable host, the free-living, non-feeding infective juvenile (IJ) enters the host via natural openings such as the anus, mouth or spiracles (Gaugler et al., 1997; Griffin et al., 2005). The bacteria grow rapidly in the nutrientrich haemolymph and produce toxins and other metabolites 
that kill the host by means of inducing septicaemia within 24 to 48 hours of infection (Gaugler et al., 1997; Ehlers, 2001; Griffin et al., 2005).

A growing amount of interest has been shown in the notable potential of Heterorhabditidae and Steinernematidae for inundative application as biocontrol agents against economically important insect pests (Griffin et al., 2005). The advantages of using nematodes are that they actively seek out well-hidden hosts and, combined with their associated bacteria, quickly kill their hosts. Despite their wide host range, they are not pathogenic to vertebrates. In addition, they are compatible with commercial rearing and application techniques (Gaugler, 1988; Bathon, 1996; Stuart et al., 1997). The commercial production of entomopathogenic nematodes as an environmentally safer option to the use of chemical insecticides can be regarded as being due to the increased understanding of their biology, and improved production methods and storage formulations (Friedman, 1990; Ehlers, 1996). According to Le Vieux and Malan (2013), such increased understanding and commercial production of EPNs are both pertinent in the pursuit of sustainable agriculture, and in helping to alleviate the global issues of species extinctions and ecosystem and biodiversity loss.

Unfortunately, only a few studies have been undertaken as of yet to test the efficacy of South African EPN species against insect pests. Even fewer tests have been done to determine the susceptibility of Pseudococcidae to EPNs. It is important that South African species of EPN should be discovered and tested. As a precautionary policy, strict regulations concerning the importing of exotic organisms into South Africa cover the importation of EPNs, among other organisms (in terms of amended Act 18 of 1989, under the Agricultural Pest Act 36 of 1947). Such regulations ultimately prevent the importing of exotic, commercially available EPNs prior to conducting a full impact study (Malan et al., 2006). The concern is that exotic nematode species might have effects on non-target South African organisms, while possibly displacing indigenous nematode species. In addition, exotic nematodes generally are not adapted well to local environmental conditions (Grewal et al., 2001; Ehlers, 2005). Increasing numbers of new South African EPN species with biocontrol potential are still in the process of being studied. Examples of such species include Steinernema citrae Stokwe, Malan \& Nguyen, 2010, Heterorhabditis safricana Malan, Nguyen \& Tiedt, 2008, Steinernema khoisanae Nguyen, Malan \& Gozel, 2006, Heterorhabditis zealandica
Poinar, 1990, Heterorhabditis bacteriophora Poinar, 1976, Heterorhabditis noenieputensis Malan, Knoetze \& Tiedt, 2013, and Steinernema yirgalemense Tesfamariam, Gozel, Gaugler \& Adams, 2004 (Malan et al., 2006, 2011).

In South Africa, Stokwe (2009) performed various bioassays on $P$. viburni, the obscure mealybug. Heterorhabditis zealandica was shown to be the most lethal candidate of 16 different local EPN strains. Both $H$. zealandica and $S$. yirgalemense were able to complete their life cycle and to reproduce in P. viburni (Stokwe \& Malan, 2010). On the testing of host size susceptibility to $H$. zealandica, the adult and intermediate life stages were shown to be the most susceptible to EPN infection, with 78\% and $76 \%$ mortality respectively (Stokwe \& Malan, 2010). Heterorhabditis zealandica was found to be able to enter the core of $P$. viburni-contaminated apples, enabling it to infect the mealybugs inside the fruit (Stokwe \& Malan, 2010).

Another South African study on mealybugs was undertaken by Van Niekerk (2012), who conducted different bioassays and field trials to determine the potential of South African EPN isolates to control Pseudococcus citri, the citrus mealybug. Tests showed that $P$. citri was most susceptible to $H$. zealandica (with $91 \%$ mortality) and S. yirgalemense (with 97\% mortality) (Van Niekerk \& Malan, 2012). Both species were able to complete their life cycles within the insect host, while $S$. yirgalemense proved to be more tolerant to lower levels of free water and faster at locating and infecting $P$. citri than H. zealandica (Van Niekerk, 2012).

In the current study, the main objective was to establish the potential of EPNs to control adult female $P$. ficus under laboratory conditions. Screening was done to determine which nematode species was the most pathogenic to P. ficus. Once established, the best two candidates concerned were exposed to biological and life cycle studies within $P$. ficus. Further laboratory bioassays were conducted to establish ideal nematode concentrations; to compare virulence levels between commercially produced and recycled commercially produced nematodes; and to establish the ability of nematodes to detect, move vertically and infect mealybugs in a sand column.

\section{MATERIALS AND METHODS}

Source of nematodes

The six South African nematode species that were used in the current study were obtained from previous local surveys and were stored in the Stellenbosch University nematode collection (Table 1) (Malan et al., 2006, 2011). IJs of the

TABLE 1

South African Steinernema and Heterorhabditis species, isolate, habitat, locality and GenBank accession number used (Malan et al., 2006, 2011).

\begin{tabular}{lllll}
\hline Species & Isolate & Habitat & Locality & GenBank accession number \\
\hline S. khoisanae & SF80 & Disturbed & Villiersdorp, Western Cape & DQ314289 \\
S. citrae & 141-C & Disturbed & Piketberg, Western Cape & EU740970 \\
S. yirgalemense & 157-C & Disturbed & Friedenheim, Mpumalanga & EU625295 \\
H. bacteriophora & SF351 & Disturbed & Wellington, Western Cape & FJ455843 \\
H. safricana & SF281 & Disturbed & Piketberg, Western Cape & EF488006 \\
H. zealandica & SF41 & Natural & Patensie, Eastern Cape & EU699436 \\
\hline
\end{tabular}


six species were cultured in vivo, using the last instar of the greater wax moth larvae, Galleria mellonella (Linnaeus) (Lepidoptera: Pyralidae) at room temperature (Griffin et al., 2005). The IJ rearing and harvesting procedures were conducted according to the methods of Kaya and Stock (1997) and White (1927). IJs from the White trap were harvested within the first week of emergence and stored horizontally in $500 \mathrm{ml}$ vented culture flasks containing approximately 150 $\mathrm{ml}$ distilled water at $14^{\circ} \mathrm{C}$. The nematodes were used within a month after harvesting. To aid in aeration and nematode survival during storage, the culture flasks were shaken weekly. The two commercially produced nematode species were obtained from e-nema (Raisdorf, Germany) and stored in the refrigerator at approximately $4^{\circ} \mathrm{C}$ for a few days before use. The nematode concentrations used for different experiments were calculated using the equation developed by Navon and Ascher (2000).

\section{Source of insects}

To ensure a constant, reliable supply of healthy mealybugs for experiments, a laboratory culture must be established. Consequently, a colony $P$. ficus was reared in the laboratory at $25^{\circ} \mathrm{C}$ on fresh butternuts within a wooden, framed cage $(650 \mathrm{~mm} \times 350 \mathrm{~mm} \times 590 \mathrm{~mm})$. The front of the cage was transparent Perspex, for ease of viewing, with insect-proof mesh on the top and sides to allow for adequate ventilation and air flow. The bottom of the cage was covered with wax paper. Clean butternuts were placed against infested butternuts to allow for the quick and easy dispersal of the $P$. ficus individuals concerned. To increase colony size, more butternuts were added, whereas rotting butternuts were discarded. Female mealybugs were removed from the butternuts using a fine paintbrush to minimise injury. The initial $P$. ficus colony was obtained from the Agricultural Research Council (ARC)-Infruitech-Nietvoorbij, Stellenbosch.

The G. mellonella larvae were reared on a diet consisting of a mixture of five parts baby cereal (Cerelac NestléTM), brown bread flour and bran, two parts yeast and wheat germ, and one part honey, and kept in a growth chamber at $28^{\circ} \mathrm{C}$.

\section{Bioassay protocol}

For the test arena, 24-well bioassay trays (Flat bottom, Nunc $^{\text {TM }}$, Cat. No. 144530, Thermo Fisher Scientific (Pty) Ltd., Gauteng, Johannesburg, South Africa) were used. The bottom of each alternate well was lined with a circular (13 $\mathrm{mm}$ diameter) piece of filter paper. Five trays were used for each treatment, as well as five trays for the control. A single adult female $P$. ficus was placed in each well and inoculated with the desired IJ concentration per $50 \mu \mathrm{l}$, using an Eppendorf micropipette. The $P$. ficus individuals in the controls received $50 \mu \mathrm{l}$ of water only. To prevent the insects from escaping, each plate was covered with a glass pane inside the lid, held closed with a rubber band. The trays were placed in plastic containers, lined with moistened paper towels and closed with a lid to ensure high humidity levels $(\mathrm{RH} \pm 95 \%)$. The trays were placed in a dark growth chamber at $25 \pm 2^{\circ} \mathrm{C}$ for $48 \mathrm{~h}$. After two days, mortality was determined and dead individuals from the treatment were removed and rinsed of external IJs. Water was then placed in small Petri dishes, which were lined with moist filter paper, sealed with PARAFILM ${ }^{\circledR}$, and placed back in the growth chamber at $25 \pm 2^{\circ} \mathrm{C}$ for another $48 \mathrm{~h}$. A water drop was placed on each of the cadavers for dissection. The cadavers were viewed with the aid of a stereomicroscope to validate that the deaths concerned had been due to nematode infection. Cadavers with visible nematodes were recorded as having been infected, while others (in both the control and treatments) were recorded as having died from natural causes.

\section{Screening}

The 24-well bioassay protocol was used to test the ability of the six endemic EPN species (Table 1) and two commercially produced EPN species to infect adult female P. ficus under optimal laboratory conditions. The bioassay protocol was followed and, in order to reduce any edge effects and thus to ensure an even distribution in the plate, the bottom of each alternative well was lined with a circular (13 mm diameter) piece of filter paper. As a result of this procedure, 12 wells were occupied per tray, each containing a single mealybug. Five trays were used for the treatment of each nematode species, and five trays for the control. Each mealybug in the treatment was inoculated with $100 \mathrm{IJs} / 50 \mu \mathrm{l}$ of water. The procedure was repeated on a separate date with a different batch of nematodes.

\section{Biological study}

The current qualitative study entailed detailing and recording the developmental progression of both $S$. yirgalemense and $H$. zealandica within adult female $P$. ficus individuals. Using the multi-well bioassay protocol, adult female mealybugs were infected, using 100 IJs of both nematode species. Two days post-inoculation, 200 infected mealybugs of each nematode species were selected and rinsed with distilled water to remove excess IJs from the surface of the insect. A total of 50 insects was placed on four damp filter papers in $13 \mathrm{~cm}$ diameter Petri dishes, and sealed with PARAFILM ${ }^{\circledR}$. Twenty-five individuals for each nematode species were selected at random, dissected and inspected at a time, beginning at $48 \mathrm{~h}$ and then again one to two days thereafter, until the life cycle was completed or ceased to continue. The mean number of IJs that penetrated the mealybugs was recorded for the first two dissections, while the life cycle progression of the nematodes, and the colour changes in the mealybug, were recorded throughout. To establish whether the two nematode species would complete their life cycle in $P$. ficus, ten infected individuals were left in White traps, with the average IJ production per mealybug being calculated for both nematode species.

\section{Effect of nematode concentrations on levels of Planococcus ficus mortality}

The effect of increasing concentrations of $S$. yirgalemense, $H$. zealandica and H. bacteriophora was tested. Five 24-well bioassay trays were used, of which eight evenly distributed wells were lined with a circular (13 mm diameter) piece of filter paper in which a single adult female mealybug was placed. The above-mentioned procedure was carried out for each of the nematode concentrations tested $(0,5,10,20,40$ 
and $80 \mathrm{IJS} / 50 \mu \mathrm{l} /$ mealybug). The trays were placed in plastic containers lined with moistened paper towels, and closed to ensure high humidity levels $(\mathrm{RH} \pm 95 \%)$. They were then placed in a dark growth chamber at $25 \pm 2{ }^{\circ} \mathrm{C}$ for $48 \mathrm{~h}$. The procedure was repeated on a separate date, using a new batch of nematodes.

\section{Virulence comparison between in vivo and in vitro nematodes}

The in vitro, commercially produced $S$. feltiae (CSf), and the commercially produced $H$. bacteriophora $(\mathrm{CHb})$ were used to determine the ability of in vitro- and in vivo-cultured EPNs to infect $P$. ficus. The commercially produced nematodes were used to inoculate $G$ mellonella larvae, and the emerged IJs were harvested as having been 'recycled' (in vivo) from White traps, and then used to inoculate the mealybugs. From this point on they therefore are referred to in the current study as recycled commercially produced $S$. feltiae (RCSf), and recycled commercially produced $H$. bacteriophora $(\mathrm{RCHb})$. The formulation IJs were also used to inoculate the mealybugs directly. The bioassay protocol was followed and 12 wells per tray were occupied, each with a single mealybug. Five trays were used for the treatment, and five trays for the control for each nematode species. Each mealybug in the treatment was inoculated with $100 \mathrm{IJs} / 50 \mu \mathrm{l}$, with the procedure being repeated on a separate date.

\section{Vertical sand column test}

The ability of $S$. yirgalemense and $H$. zealandica to detect and infect adult female P. ficus in vertically placed sand columns was tested. Five mealybugs were placed in a single perforated PCR $0.2 \mathrm{ml}$ tube (using a heated surgical needle). The tube was then placed at the bottom of a $15 \times 1.5 \mathrm{~cm}$ centrifuge tube. To sterilise the river sand it was frozen at $-40^{\circ} \mathrm{C}$, and dried in an oven overnight at $50^{\circ} \mathrm{C}$. To ensure adequate moisture levels, water and sand were mixed in a ratio of $1: 10 \mathrm{v} / \mathrm{v}$. Each centrifuge tube was filled with sand to the top. A $13 \mathrm{~mm}$ diameter piece of filter paper was inoculated with 500 IJs. The inoculated side was placed downward and left on top of the sand. The lid of the centrifuge tube was screwed on, after which the tube was placed vertically in a dark growth chamber at $25 \pm 2{ }^{\circ} \mathrm{C}$ for $48 \mathrm{~h}$. For each nematode species, 20 tubes (i.e. 100 mealybugs in total) were used, and the experiment was repeated on a separate date with a new batch of nematodes.

\section{Data analysis}

All statistical analyses were done using STATISTICA version 11 (StatSoft Inc., 2012). All data, except for the concentration trials, were corrected in order to compensate for natural deaths by using Abbott's formula (Abbott, 1925). An analysis of variance (ANOVA) was used to analyse the data. A posthoc comparison of means was done using Bonferroni's method, or, when residuals were not distributed normally, a bootstrap multi-comparison of means was conducted, with 95\% confidence intervals (Efron \& Tibshirani, 1993). Data from different test dates were pooled. A probit analysis was performed using Polo PC (LeOra Software 1987) to determine lethal nematode dosages (Finney, 1971).

\section{RESULTS}

\section{Screening}

Data analysed with a two-way ANOVA showed no significant difference between the species and the two test dates $\left(\mathrm{F}_{(7,64)}\right.$ $=1.189 ; P=0.32)$. Data from the two batches were pooled, showing significant differences $\left(\mathrm{F}_{(7,72)}=26.263 ; P<0.001\right)$ when comparing the species. Percentage mortality ranged from $5 \pm 2 \%$ (H. safricana) to $96 \pm 2 \%$ (H. zealandica)

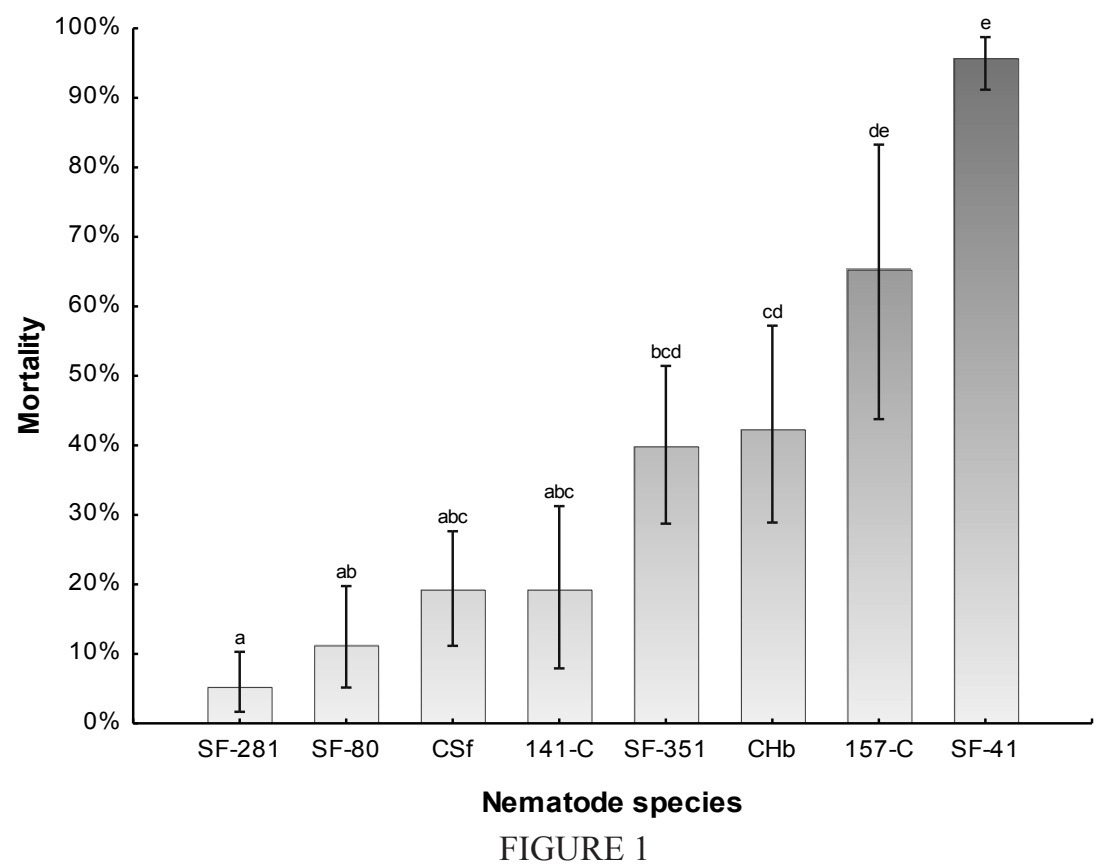

The mean percentage mortality ( $95 \%$ confidence interval) of adult female Planococcus ficus inoculated with Heterorhabditis safricana (SF281), Steinernema khoisanae (SF80), commercially produced S. feltiae (CSf), S. citrae (141-C), H. bacteriophora (SF351), commercially produced $\mathrm{H}$. bacteriophora $(\mathrm{CHb})$, S. yirgalemense (157-C) and H. zealandica (SF41), at a concentration of $100 \mathrm{IJs} / 50 \mu \mathrm{l} /$ insect after $48 \mathrm{~h}$ (one-way ANOVA; $\mathrm{F}(7,72)=26.263 ; \mathrm{P}<0.001$ ). Bars sharing a common letter are not significantly different. 
(Fig. 1). The $96 \%$ mortality caused by $H$. zealandica was significantly higher than the mortality that was obtained with all other isolates, except for $S$. yirgalemense, which had a mortality of $65 \pm 10 \%$. The two commercially produced species, CSf and $\mathrm{CHb}$, did not differ significantly from each other $(P=0.23)$, although CSf was only responsible for a $19 \pm 4 \%$ mortality, in comparison to $\mathrm{CHb}$, with a $42 \pm 7 \%$ mortality. Although the mean mortality differed by $23 \%$, no significant difference was found between $S$. yirgalemense and commercially produced $H$. bacteriophora $(P=0.23)$.

\section{Biological study}

For both $H$. zealandica and S. yirgalemense, development and visual changes in the infected mealybugs were documented for a total of 14 days after inoculation (Table 2). Planococcus ficus individuals infected by $H$. zealandica ranged from yellow, orange to dark brown/black in colour within $48 \mathrm{~h}$ of infection. When the yellow individuals were opened for inspection, their internal contents were easily separated in water, in comparison to the internal contents of the orange and dark-brown individuals, which were viscous and gummy in consistency. By day three, eggs were visible within the hermaphroditic $H$. zealandica adults. On day six, larvae were apparent inside the adults, while the first emergent IJs were visible on day eight, completing the life cycle. A mixture of IJs and adults with larvae was present on day 10 , but from day 14 onwards only IJs were found. The mean IJ penetration was $13(n=50)$, with a penetration range of one to $37 \mathrm{IJs}$ for a single mealybug. The mean IJ production per cadaver of $H$. zealandica was 300 .

Mealybugs infected with $S$. yirgalemense also produced the same colour changes. Two days after inoculation, mealybug individuals were yellow, orange or brown/black in colour. It was also observed that the darker the colour, the thicker the viscosity of the mealybugs' internal matrix, due to the higher bacterial concentration levels. Adults were present by day three, with females containing eggs and males being clearly distinguishable due to their diagnostic spicule. On day six, larvae were present in the adult females. Day seven presented a mixture of larvae and adult females containing larvae. IJs were present from day nine through to 14, while the pre-adults did not mature and began dying by day 14 . Some mealybug individuals contained no IJs, but only preadults, which eventually died. The mean IJ penetration was six $(n=50)$, with a penetration range of one to 23 IJs for a single mealybug. The mean IJ production per cadaver for S. yirgalemense was 75 .

\section{Virulence comparison between nematodes grown in vitro and in vivo}

A four-way ANOVA showed no significant differences between batches (two levels: batch 1 and batch 2 , used on separate dates), between the species (two levels: $S$. feltiae and $H$. bacteriophora), between formulations (recycled and not recycled), or between treatments (two levels: treatment and control $)\left(\mathrm{F}_{(1,64)}=0.05924 ; P=0.808\right)$.

Data from the two batches were pooled and a two-way ANOVA was used to compare species and formulations $\left(\mathrm{F}_{(1,36)}=0.68787 ; P=0.412\right)$. Although no significant overall interaction was indicated, there was a significant difference between RCSf and non-recycled CSf $(P=0.048)$ when the performances of the two species were investigated separately. Percentage mortality for $\mathrm{RCHb}$ and $\mathrm{CHb}$ was $54 \pm 5 \%$ and $42 \pm 5 \%$ respectively, with $\mathrm{RCHb}$ being responsible for a $12 \%$ higher mortality in adult female $P$. ficus (Fig. 2).

\section{Effect of nematode concentration on Planococcus ficus mortality}

Results analysed using a three-way ANOVA showed no significant differences between the species (three levels: $S$. yirgalemense, $H$. zealandica and $\mathrm{CHb}$ ), nematode concentration (six levels: 0, 5, 10, 20, 40, $80 \mathrm{IJs} /$ insect) and different batches (two levels: batch 1 and batch 2, used on separate dates) $\left(\mathrm{F}_{(10,144)}=1.549 ; P=0.13\right)$. Data from the two batches were pooled, and a two-way ANOVA comparing the different species and six concentrations showed significant differences $\left(\mathrm{F}_{(10,162)}=2.828 ; P<0.05\right)$. The only significant difference at a given concentration was between the commercially produced $H$. bacteriophora $(\mathrm{CHb})$ and the other two species, at a concentration of 80 IJs/mealybug $(P<0.001)$. Heterorhabditis bacteriophora produced a mean mortality of $62 \pm 7.4 \%$, while $H$. zealandica and $S$. yirgalemense both produced a mean mortality of 94 $\pm 2.7 \%$ at a concentration of $80 \mathrm{IJS} /$ mealybug. At all other given concentrations, there was no significant difference between the species (Fig. 3).

The $\mathrm{LC}_{50}$ and $\mathrm{LC}_{90}$ of $P$. ficus, after exposure to H. zealandica, S. yirgalemense and $\mathrm{CHb}$ for $24 \mathrm{~h}$, were 19 $\mathrm{IJS} /$ mealybug and $82 \mathrm{IJ} /$ mealybug; $13 \mathrm{IJs} /$ mealybug and 80 IJs/mealybug; and $36 \mathrm{IJs} /$ mealybug and $555 \mathrm{IJs} /$ mealybug respectively (Fig. 4). The $\mathrm{LC}_{90}$ for the $\mathrm{CHb}$ extends beyond the scope of the graph.

\section{Vertical sand column test}

The percentage mortality of the pooled data was analysed using a one-way ANOVA. A significant difference was found between the performance of $S$. yirgalemense and $H$. zealandica $\left(\mathrm{F}_{(1,78)}=8.878 ; P=0.003\right)$. The mean percentage mortality for $H$. zealandica and $S$. yirgalemense was $82 \pm 4.1 \%$ and $95 \pm 1.4 \%$ respectively (Fig. 5).

\section{DISCUSSION}

The study of the use of EPNs for the control of P. ficus is novel. In such investigations, the first and most important step when considering the potential use of EPNs as a biological control agent against P. ficus is to determine the virulence of the different nematode species under optimum environmental conditions.

The research has shown, through the screening of six indigenous EPN species and two commercially produced species, that there are clear differences in pathogenicity between the nematode species concerned. Under optimal laboratory conditions, $H$. zealandica outperformed the other seven nematode species, with a mean mortality of $95 \%$, while $H$. safricana scored a mean mortality of only $5 \%$. The results obtained illustrate the range in susceptibility of the host against the different species. Steinernema yirgalemense produced the second best mean mortality result of $65 \%$, but with no significant difference in relation to $H$. zealandica and $H$. bacteriophora. These results are similar to and 
complement earlier work conducted on different mealybug species, specifically on P. viburni by Stokwe (2009) and on P. citri by Van Niekerk and Malan (2012). Heterorhabditis zealandica and $S$. yirgalemense were among the four most pathogenic species in the study conducted by Stokwe (2009), while they were the best two species, producing very high percentages of mortality, of $91 \%$ and $97 \%$ respectively, in Van Niekerk and Malan's (2012) study.
Interestingly, studies on other insect pests have shown similar promising results concerning $H$. zealandica and $S$. yirgalemense. Specifically, H. zealandica was selected as the best candidate for the control of codling moth, Cydia pomonella (L.), by De Waal (2008), Malan et al. (2011) showed $S$. yirgalemense to be highly virulent against false codling moth, Thaumatotibia leucotreta (Meyrick), while the work conducted by Ferreira and Malan (2013) held

TABLE 2

Heterorhabditis zealandica and Steinernema yirgalemense development in adult female Planococcus ficus.

\begin{tabular}{|c|c|c|c|}
\hline $\begin{array}{l}\text { Nematode } \\
\text { species }\end{array}$ & $\begin{array}{l}\text { Number of } \\
\text { days post } \\
\text { inoculation }\end{array}$ & Developmental stage & $\begin{array}{l}\text { Mean and range } \\
\text { of } \mathrm{IJ} \text { penetration } \\
(\mathrm{n}=50)\end{array}$ \\
\hline \multirow[t]{8}{*}{ H. zealandica } & 2 & Mixture of unrecovered IJs and recovered pre-adult stages & $13(1-37)$ \\
\hline & 3 & Mixture of recovered pre-adult stages and hermaphrodites with eggs & \\
\hline & 4 & Hermaphrodites with eggs & - \\
\hline & 6 & Mixture of hermaphrodites with eggs and hermaphrodites with larvae & - \\
\hline & 8 & Mixture of hermaphrodites with eggs and larvae and first-generation IJs & - \\
\hline & 9 & Mixture of hermaphrodites with eggs and larvae and IJs & - \\
\hline & 10 & Mixture of hermaphrodites with larvae and IJs & - \\
\hline & 14 & IJs only & - \\
\hline \multirow[t]{8}{*}{ S. yirgalemense } & 2 & Mixture of unrecovered IJs and recovered pre-adult stages & $6(1-23)$ \\
\hline & 3 & Mixture of recovered pre-adults and adults (females containing eggs) & \\
\hline & 4 & Mixture of pre-adults and adults (females containing eggs) & - \\
\hline & 6 & Males and females filled with larvae & - \\
\hline & 7 & Males and females filled with larvae and immature stages & - \\
\hline & 9 & Immature stages and IJs & - \\
\hline & 12 & Immature stages and IJs & - \\
\hline & 14 & Immature stages and IJs & - \\
\hline
\end{tabular}

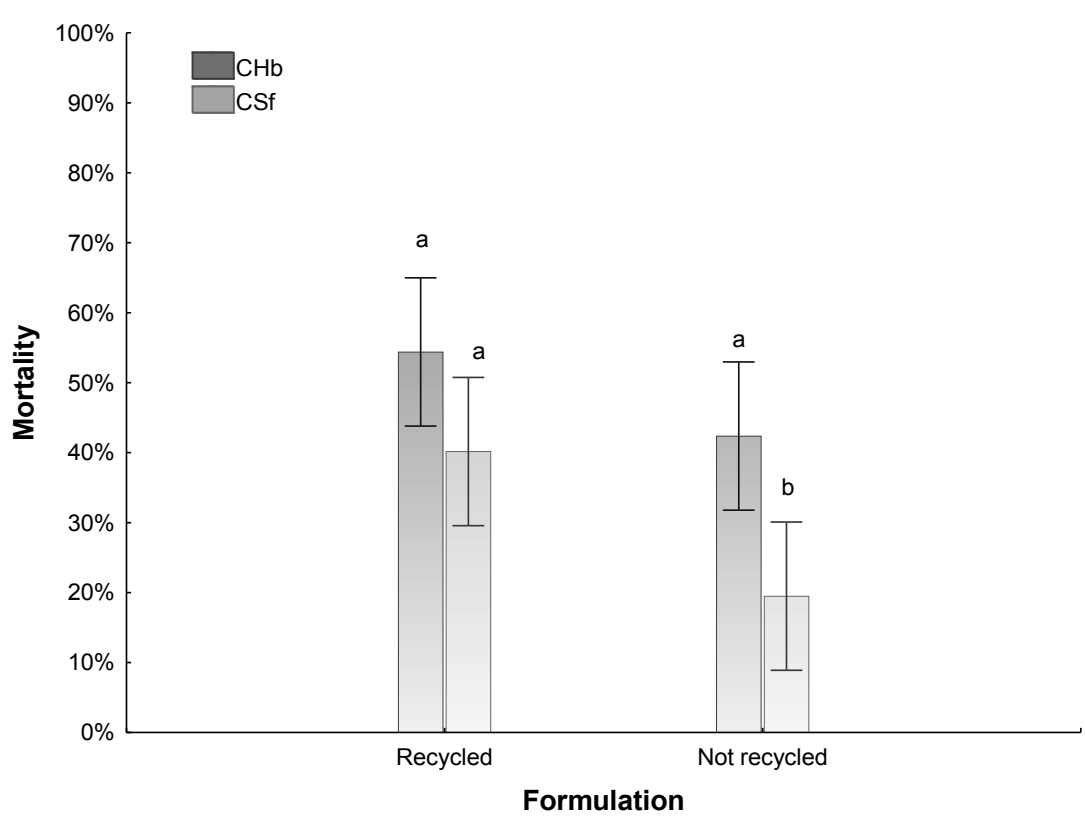

FIGURE 2

The mean percentage mortality (95\% confidence interval) of female adult Planococcus ficus infected with commercially produced Heterorhabditis bacteriophora and Steinernema feltiae (CHb and $\mathrm{CSf}$ ), and recycled commercially produced $\mathrm{H}$. bacteriophora and S. feltiae (RCHb and RCSf), at a concentration of $100 \mathrm{IJs} / 50 \mu \mathrm{l} /$ insect after $48 \mathrm{~h}$ (two-way ANOVA; F(1, 36) $=0.68787, \mathrm{P}=0.412$ ). Bars sharing a common letter are not significantly different. 
H. zealandica responsible for the highest mortality levels of the banded fruit weevil, Phlyctinus callosus (Schönherr). Of the commercially produced EPNs, H. bacteriophora was found not to be significantly different from commercially produced $S$. feltiae. The general performance of the two families is varied, and, considering that $H$. zealandica and $S$. yirgalemense were the best, potential arguments concerning the generally superior performance of heterorhabditids in relation to steinernematids (leading to speculation about heterorhabditids and the possession of a dorsal tooth that might promote increased levels of penetration, thus encouraging better performance) can be disregarded. When considering the current study and previous studies, these two species clearly displayed highly virulent qualities to a variety of insect pests, including P. ficus, and therefore were selected for further tests.

A biological study was done to gain insight into whether or not the EPNs of interest can develop and complete their life cycle in P. ficus. If they were able to do so it would affect the success and persistence of the biocontrol agent in vineyards, where it could have significant effects not only on mealybugs, but also on other soil stages of pest insects such

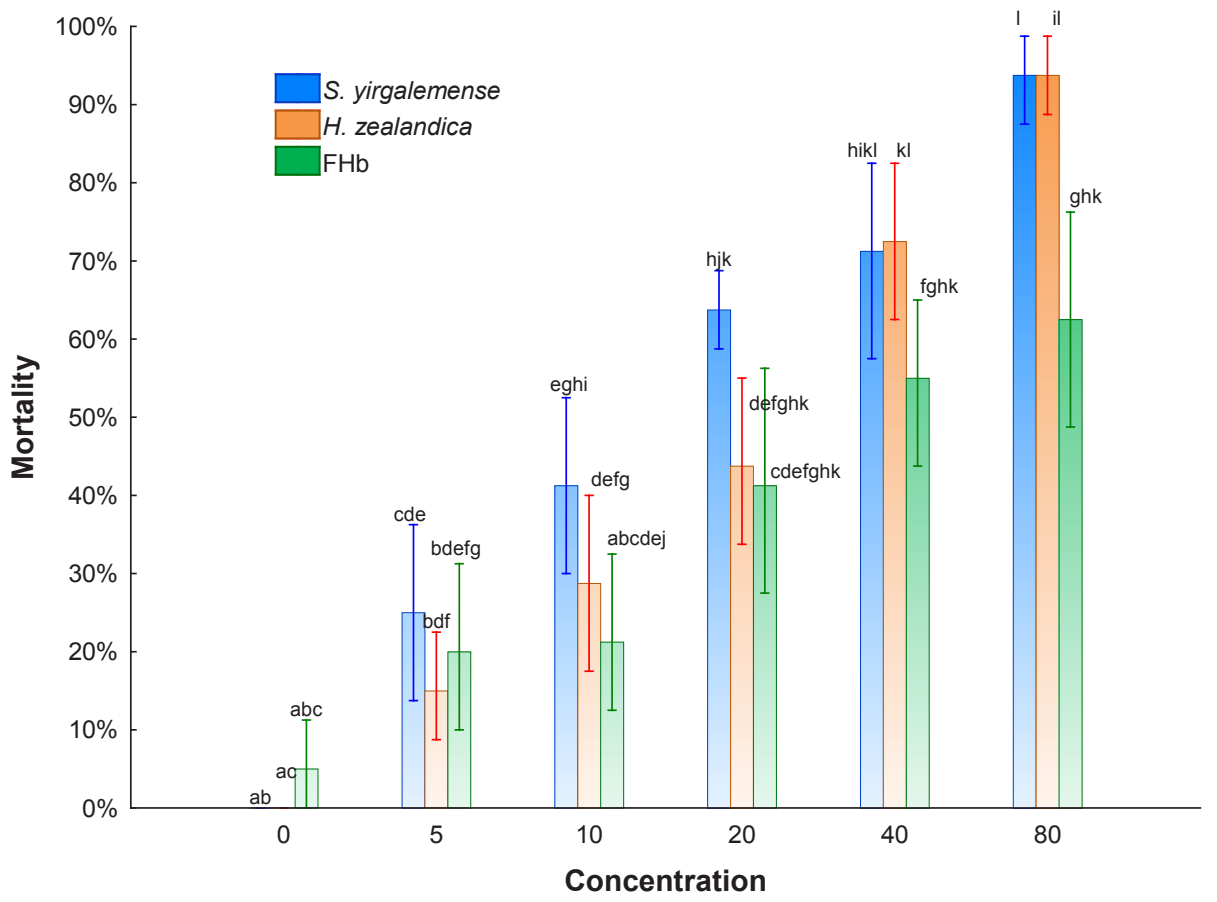

FIGURE 3

The mean percentage mortality (95\% confidence interval) of female adult Planococcus ficus infected with Steinernema yirgalemense, Heterorhabditis bacteriophora and commercially produced Heterorhabditis bacteriophora $(\mathrm{CHb})$ at 0,5 , 10, 20, 40 and $80 \mathrm{IJs} /$ mealybug after 48 h (two-way ANOVA; F $(10,162)=2.828 ; \mathrm{P}<0.05$ ). Bars with different letters indicate a significant difference.

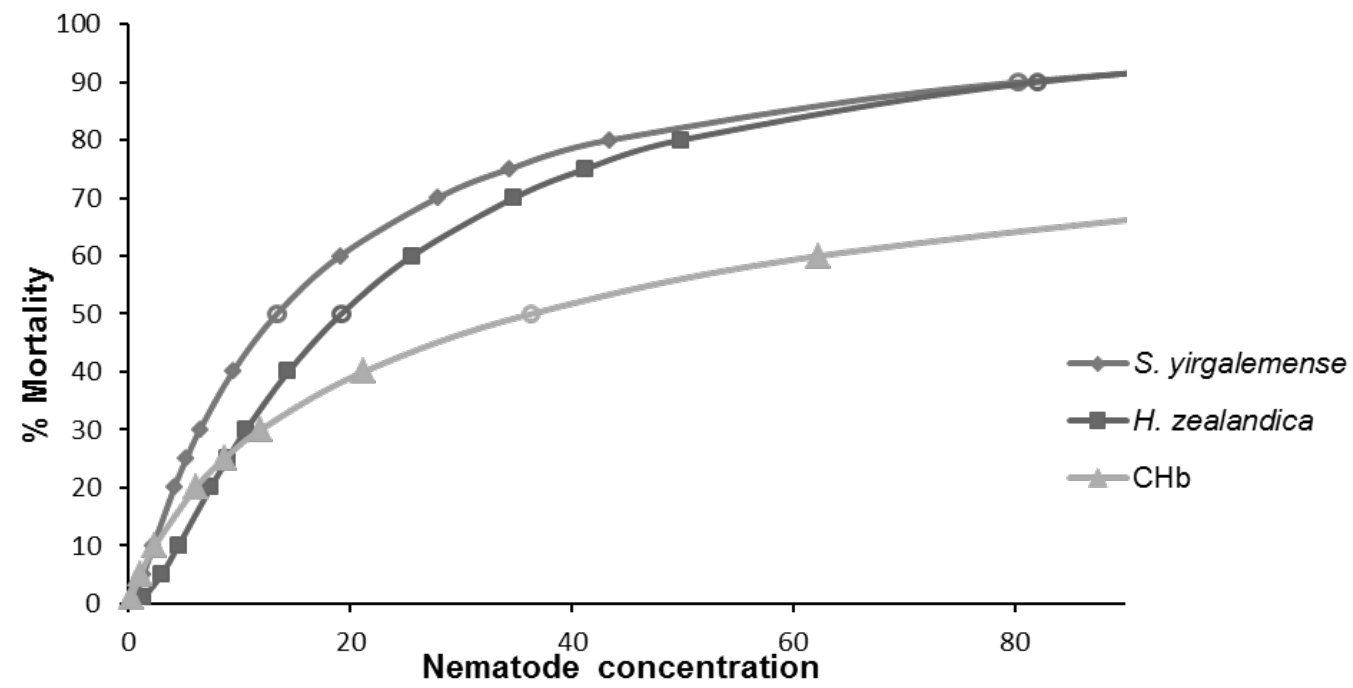

FIGURE 4

The mean percentage mortality of adult female Planococcus ficus $48 \mathrm{~h}$ after exposure to Heterorhabditis zealandica, Steinernema yirgalemense and commercially produced Heterorhabditis bacteriophora (CHb). The LC50 and LC90 values of each species are indicated on the curves by circular markers (probit analysis). 


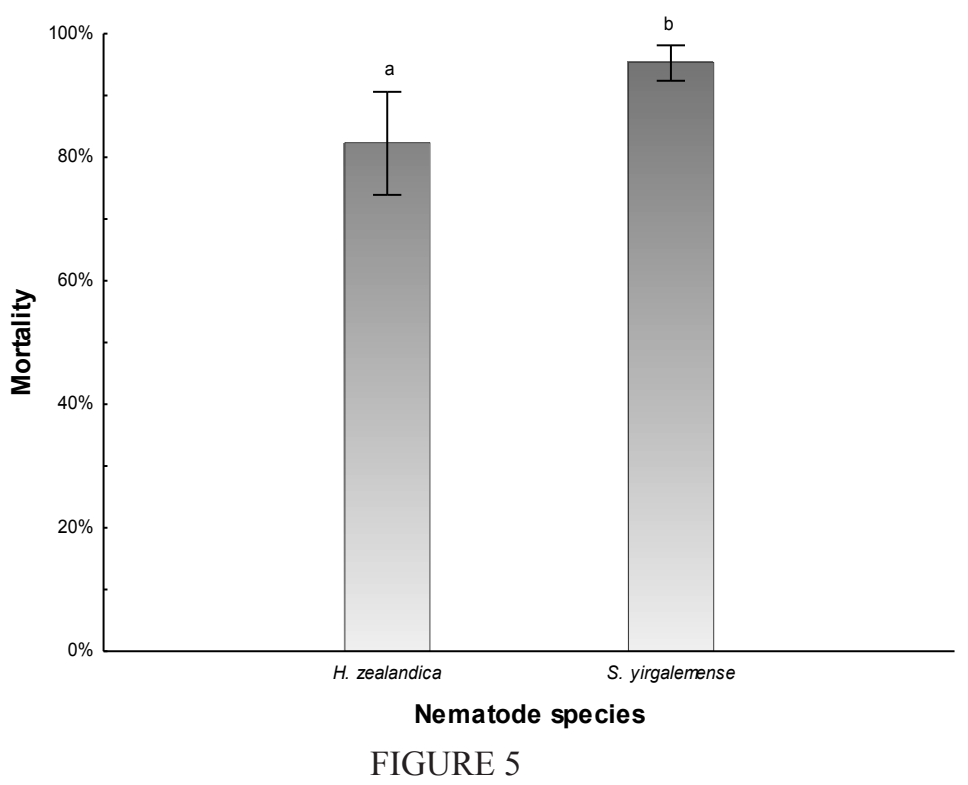

The mean mortality (95\% confidence interval) of female adult Planococcus ficus $48 \mathrm{~h}$ after being buried under $15 \mathrm{~cm}$ of sand after inoculation with Heterorhabditis zealandica and Steinernema yirgalemense at a concentration of 100 IJs/mealybug (oneway ANOVA; $\mathrm{F}(1,78)=8.878 ; \mathrm{P}=0.003)$. Different letters indicate significant differences.

as $P$. callosus.

When inspecting the cadavers two days after inoculation, the mean penetration number of $H$. zealandica exceeded the number of $S$. yirgalemense, with numbers of 16 and six respectively. The results were complemented by the mean penetration numbers established by Stokwe (2009) and Van Niekerk and Malan (2012), who both found higher penetration levels with $H$. zealandica than $S$. yirgalemense. The higher penetration number of $H$. zealandica corresponds to its superior performance in the screening test. There is an apparent direct relationship between penetration and insecticidal activity, a finding that is supported by Hominick and Reid (1990), who assumed that the nematode with the highest efficacy against the insect of interest would also have the best invasion efficacy. The findings of various other studies on different insect pests are in accordance with these findings (Kondo \& Ishibashi, 1986; Mannion \& Jansson, 1993; Shannag et al., 1994; Garcia del Pino \& Morton, 2005). The relatively low penetration numbers in comparison to the numbers that have been obtained with other insect hosts can be ascribed to the small size of the adult female P. ficus, which is approximately $4 \mathrm{~mm}$ in length and $2 \mathrm{~mm}$ in width.

Although both nematode species completed their life cycles, the amount of time that was taken to do so varies by a day or two in comparison to the amount of time that was taken in biological studies conducted by Stokwe (2009) and by Van Niekerk and Malan (2012). The variation could be attributed to the different sizes of the mealybugs concerned, although they were very similar. The life cycle of $S$. yirgalemense was found to be longer in P. ficus, not shorter, as had been found in the other two studies and with the associated mealybug species. The development of $S$. yirgalemense in P. ficus was similar to that described in the findings of Van Niekerk and Malan (2012) in relation to $P$. citri, which was found to produce IJs, although in some instances the nematodes only developed to a certain stage and then perished. In general, the factors that cause the development of IJs and their movement out of the host are the availability of food and the overcrowding of nematodes in the host cadaver (Ehlers, 2001; Adams \& Nguyen, 2002; Griffin et al., 2005). Thus, overcrowding and/or nutrient deficiencies will prompt the development of IJs and their movement out of the host in search of a new host. According to Smart (1995), the time taken from IJ entry into the host until IJ emergence is also dependent on the nematode species concerned and on the ambient temperatures. Factors such as these could explain the differences in the development and developmental times between the two EPN species of the three different mealybugs involved.

According to Gaugler and Georgis (1991), the quality of inoculum produced by various methods has received little attention. Accordingly, two EPN species that had been produced commercially in a liquid medium and stored in a unique formula were tested against the same commercially produced species that were recycled through wax moth larvae. In both instances, the recycled in vivo individuals caused a higher mean mortality. For H. bacteriophora, the recycled IJs caused a mean mortality of $54 \%$, as opposed to $42 \%$, with no significant difference in effect from the results obtained with the commercially produced individuals. However, a significant difference was detected between the commercially produced and recycled IJs of $S$. feltiae, with a respective mean mortality of $19 \%$ and $40 \%$.

Due to the fact that the production of EPNs by in vivo methods is laborious, and limited by scale and economy, it is important that commercially produced nematodes are able to reach their full potential as biopesticides (Gaugler \& Georgis, 1991; Ehlers, 2001). Unfortunately, many disadvantages are associated with large-scale production (Ehlers, 2001). Besides the problems that are associated with the actual mass (in vitro) culturing process itself, and transport and storage, some studies have shown the pathogenicity of the EPNs to be compromised during the in vitro process. For example, Yang et al. (1997) found that the quality of EPNs 
was influenced by the type of culture medium concerned. Both Gaugler and Georgis (1991) and Yang et al. (1997) found in vivo culturing methods to produce IJs with higher fatty acid content. According to Gaugler and Georgis (1991), a reduction in the fatty acid content of IJs produced in vitro causes a reduction in pathogenicity, but such information is challenged by Ehlers (personal communication, 2013) who has found that there is no difference in the total fatty acid content of IJs when produced either in vivo or in vitro. The most likely reason for a reduction in pathogenicity includes prolonged storage and suboptimal storage conditions (Gaugler \& Georgis, 1991).

A definite positive relationship exists between the concentration of all three nematode species used for inoculation and the percentage mortality of $P$. ficus. For all three species there was no significant difference between the percentage mortality at a given concentration, besides that of $80 \mathrm{IJs} /$ mealybug. No significant differences were detected between $H$. zealandica, S. yirgalemense and the commercially produced $H$. bacteriophora from the inoculum concentration of $10 \mathrm{IJs} /$ mealybug upward. The LC50 and LC90 values for $H$. zealandica in the current study were 19 and 82 IJs respectively, with the values being very similar to the LC50 and LC90 values for S. yirgalemense, at 13 and 80 respectively. In contrast, the $\mathrm{LC}_{50}$ and $\mathrm{LC}_{90}$ for $\mathrm{CHb}$ were greater than they were for both $H$. zealandica and $S$. yirgalemense, with values of 36 and 555 respectively. The similarity in the percentage of $P$. ficus mortality caused by $H$. zealandica and $S$. yirgalemense in the concentration test was similar to the P. citrus percentage mortality found by Van Niekerk and Malan (2012). Despite this finding, the LC50 value of $H$. zealandica in the current study was similar to the LC50 in Van Niekerk and Malan's (2012) study, at 11, although the $\mathrm{LC}_{90}$ values differed greatly, with Van Niekerk and Malan (2012) obtaining a value of 162 nematodes, in contrast to 82 . From the findings of the present study, as well as those of previous studies, $P$. ficus and $P$. citri clearly are more susceptible to $H$. zealandica than is $P$. viburni. Stokwe (2009), in contrast, obtained $\mathrm{LC}_{50}$ and $\mathrm{LC}_{90}$ values of 54 and 330 for $P$. viburni. The $\mathrm{LD}_{90}$ values of $H$. zealandica and S. yirgalemense in the current study give a fair indication of nematode concentrations to be used in future field studies and trials.

Sand column tests were conducted to predict the potential performance of the two best EPN candidates in the field, while also establishing which nematode species would be used for future field trials. Field soil applications are being considered because P. ficus has been found to move down to the lower regions and underground onto the roots of the vine to overwinter, providing an opportunity to control them effectively with EPNs (Walton \& Pringle, 2004a). Of the two nematode species, $S$. yirgalemense outperformed $H$. zealandica significantly, with a mean mortality of $95 \%$ and $82 \%$ respectively. Despite this outcome, both candidates performed well, and $H$. zealandica should not be disregarded completely, especially when considering previous work that has been performed and the successful results that have already been achieved. Ferreira and Malan (2013) conducted soil column tests by inoculating $P$. callosus larvae placed at different depths, with the deepest at $15 \mathrm{~cm}$, with
H. zealandica, which were then left for seven days. No significant differences in mortality were found between the burial depths. In the current study, despite the nematodes being given only two days to detect and infect $P$. ficus placed $15 \mathrm{~cm}$ deep, high mortality levels were obtained. The reason for the better performance of $S$. yirgalemense is unclear, as there are many factors that could be at play. For instance, Koppenhoffer and Fuzy (2006) found different soil types to influence the infectivity of different nematode species. To place an onus on their potentially different foraging strategies would be weak reasoning, when considering that nematode species can be placed on a continuum ranging from cruise to ambush, while nematodes have been found to shift along such a continuum (Lewis et al., 1992, 2006). Ultimately, the vertical movement of both nematode species tested in the current study was adequate for locating and infecting $P$. ficus below the soil to a depth of at least $15 \mathrm{~cm}$.

According to the results from the various bioassays, both $S$. yirgalemense and $H$. zealandica have displayed potential as good candidates for the control of P. ficus. This suggests the need for further studies to be conducted in the hope of developing an adequate infrastructure for the commercial production of South African EPNs. The commercial production and the use of indigenous nematode species for the control of agricultural pests such as P. ficus, rather than exotic species, should prevent the need to deal with potential environmental issues in the foreseeable future. Both $S$. yirgalemense and $H$. zealandica performed similarly throughout the bioassays, with $S$. yirgalemense generally doing slightly better, indicating the potential for better infield performance, where it will be likely to experience suboptimal conditions. Steinernema yirgalemense performed well in the soil column tests, which offers possibilities when considering the vertical movement of $P$. ficus down the trunk of the vine and underground onto the roots in late autumn and winter. As a result, the negative aspects of foliar application could possibly be avoided if EPNs are used in an IPM scheme to control P. ficus, as soil and lower-trunk application is possible. During the winter months, moisture levels are generally relatively high and the temperatures are relatively cool. Further tests should be conducted in the field to confirm such speculation, and to answer questions about when and how to apply the nematodes, as well as in what concentrations. In addition, their compatibility with agrochemicals should be determined.

\section{LITERATURE CITED}

Abbott, W.S., 1925. A method of computing the effectiveness of an insecticide. J. Econ. Entomol. 18, 265-267.

Adams, B.J. \& Nguyen, K.B., 2002. Taxonomy and systematics. In: Gaugler, R. (ed). Entomopathogenic nematology. CAB International, Wallingford, UK. pp. $1-28$.

Bathon, H., 1996. Impact of entomopathogenic nematodes on non-target hosts. Biocontrol. Sci. Technol. 6, 421-434.

Daane, K.M., Cooper, M.L., Triapitsyn, S.V., Walton, V.M., Yokota, G.Y., Haviland, D.R., Bentley, W.J., Godfrey, K. \& Wunderlich, L.R., 2008. Vineyard managers and researchers seek sustainable solutions for mealybugs, a changing pest complex. Calif. Agr. 62, 167-176. 
Daane, K.M., Malakar-Kuenen, R., Guillen, M., Bentley, W.J., Bianchi, M. \& Gonzalez, D., 2003. Abiotic and biotic pest refuges hamper biological control of mealybugs in California vineyards. In: $1^{\text {st }}$ Intern. Symp. on Biological Control of Arthropods, Honolulu, pp. 389 - 398.

De Waal, J.Y., 2008. Entomopathogenic nematodes (Rhabditida: Steinernematidae and Heterorhabditidae) for the control of codling moth, Cydia pomonella (L.) under South African conditions. Thesis, Stellenbosch University, Private Bag X1, Matieland (Stellenbosch), South Africa.

Douglas, N. \& Kruger, K., 2008. Transmission efficiency of grapevine leafroll-associated virus 3 (GLRaV-3) by the mealybugs Planococcus ficus and Pseudococcus longispinus (Hemiptera: Pseudococcidae). Plant. Pathol. $122,207-212$

Efron, B. \& Tibshirani, R., 1993. An introduction to the bootstrap. Chapman \& Hall, London.

Ehlers, R., 1996. Current and future use of nematodes in biocontrol: Practice and commercial aspects with regard to regulatory policy issues. Biocontrol. Sci. Technol. 6, 303-316

Ehlers, R., 2001. Mass production of entomopathogenic nematodes for plant protection. Appl. Microb. Technol. 56, 623-633.

Ehlers, R., 2005. Forum on safety and regulation. In: Grewal, P.S., Ehlers, R.-U. \& Shapiro-Ilan, D.I. (eds). Nematodes as biocontrol agents. CAB International, Wallingford, UK. pp. $107-114$

Ferreira, T. \& Malan, A.P., 2013. Potential of entomopathogenic nematodes for the control of the banded fruit weevil, Phlyctinus callosus (Schönherr) (Coleoptera: Curculionidae). J. Helminthol. 3, 1-9.

Finney, D.J., 1971. Probit analysis. Cambridge University Press, New York.

Flaherty, D.L., Peacock, W.L., Bettiga, L. \& Leavitt, G.M., 1982. Chemicals losing effect against grape mealybug. Calif. Agr. 36, 6 .

Franco, J.C., Zada, A. \& Mendel, Z., 2009. Novel approaches for the management of mealybug pests. In: Ishaaya, I. \& Horowitz, A.R. (eds). Biorational control of arthropod pests: Application and resistance management. Springer Science, New York. pp. $233-278$.

Friedman, M.J., 1990. Commercial production and development. In: Gaugler, R. \& Kaya, H.K. (eds). Entomopathogenic nematodes in biocontrol. CRC Press, Boca Raton, FL. pp. 153 - 172.

Garcia Del Pino, F. \& Morton, A., 2005. Efficacy of entomopathogenic nematodes against neonate larvae of Capnodis tenebrionis (L.) (Coleoptera: Buprestidae) in laboratory trials. BioControl 50: 307-316.

Gaugler, R., 1988. Ecological considerations in the biological control of soil-inhabiting insects with entomopathogenic nematodes. Agr. Ecosyst. Environ. 24, 351-360.

Gaugler, R. \& Georgis, R., 1991. Culture method and efficacy of entomopathogenic nematodes (Rhabditida: Steinernematidae and Heterorhabditidae). Biol. Control. 1, 269-274.

Gaugler, R., Lewis, E. \& Stuart, R.J., 1997. Ecology in the service of biological control: The case of entomopathogenic nematodes. Oecologia 9 , 483-489.

Grewal, P.S., De Nardo, A.B. \& Aguillera, M.M., 2001. Entomopathogenic nematodes: Potential for exploration and use in South America. Neotrop. Entomol. 30, 191-205.

Griffin, C.T., Boemare, N.E. \& Lewis, E.E., 2005. Biology and behaviour. In: Grewal, P.S., Ehlers, R.-U. \& Shapiro-Ilan, D.I. (eds). Nematodes as biocontrol agents. CABI Publishing, Wallingford, UK. pp. $47-75$.

Haviland, D.R., Bentley, W.J. \& Daane, K.M., 2005. Hot-water treatments for control of Planococcus ficus (Homoptera: Pseudococcidae) on dormant grape cuttings. Econ. Entomol. 98, 1109-1115.
Holm, K., 2008. Construction of a cDNA library for the vine mealybug, Planococcus ficus (Signoret). Thesis, Stellenbosch University, Private Bag X1, Matieland (Stellenbosch), South Africa.

Hominick, W.M. \& Reid, A.P. 1990. Perspectives on entomopathogenic nematology. In: Gaugler, R. \& Kaya, H.K. (eds). Entomopathogenic nematodes in biological control. CRC Press, Boca Raton, FL. pp. 327 - 343

Kaya, H.K. \& Stock, S.P., 1997. Techniques in insect nematology. In: Lacey, L.A. (ed). Manual of techniques in insect pathology. Academic Press, London. pp. $281-301$.

Kondo, E. \& Ishibashi, N., 1986. Infectivity and propagation of entomogenous nematodes, Steinernema spp., on the common cutworm, Spodoptera litura (Lepidoptera: Noctuidae). Appl. Entomol. Zool. 21, 95108.

Koppenhoffer, A.M. \& Fuzy, E.M., 2006. Effects of soil type on infectivity and persistence of the entomopathogenic nematodes Steinernema scarabaei, Steinernema glaseri, Heterorhabditis zealandica, and Heterorhabditis bacteriophora. J. Invert. Pathol. 92, 11-22.

Kriegler, P.J., 1954. 'n Bydrae tot die kennis van Planococcus citri (Risso) (Homoptera: Pseudococcidae) (in Afrikaans). Thesis, University of Stellenbosch, Private Bag X1, Matieland (Stellenbosch), South Africa.

Le Vieux, P. \& Malan, A.P. 2013. Entomopathogenic nematodes for the control of the vine mealybug (Planococcus ficus) in South African wine and table grapes: A review. S. Afr. J. Enol. Vitic. 34, 108-118.

Lewis, E.E., Campbell, J., Griffin, C., Kaya, H. \& Peters, A., 2006. Behavioural ecology of entomopathogenic nematodes. Biol. Control. 38, 66-79.

Lewis, E.E, Gaugler, R. \& Harrison, R., 1992. Entomopathogenic nematode host finding: Response to host contact cues by cruise and ambush foragers. Parasitol. 105, 309-315.

Malan, A.P., Knoetze, R. \& Moore, S.D., 2011. Isolation and identification of entomopathogenic nematodes from citrus orchards in South Africa and their biocontrol potential against false codling moth. J. Invert. Pathol. 108, 115-125.

Malan, A.P., Nguyen, K.B. \& Addison, M.K., 2006. Entomopathogenic nematodes (Steinernematidae and Heterorhabditidae) from the southwestern parts of South Africa. Afri. Pl. Prot. 12, 65-69.

Mannion, C.M. \& Jansson, R.K., 1993. Infectivity of five entomopathogenic nematodes to the sweet potato weevil, Cylas formicarius (F.) (Coleoptera: Apionidae), in three experimental arenas. J. Invert. Pathol. 62, 29-36.

Miller, D.R., Miller, G.L. \& Watson G.W., 2002. Invasive species of mealybugs (Hemiptera: Pseudococcidae) and their threat to U.S. agriculture. Proceedings of the Entomological Society of Washington 104, 825-836.

Navon, A. \& Ascher, K.R.S., 2000. Bioassays of entomopathogenic microbes and nematodes. CAB International, Wallingford, UK.

Shannag, H.K., Webb, S.E. \& Capinera, J.L., 1994. Entomopathogenic nematode effect on pickleworm (Lepidoptera: Pyralidae) under laboratory and field conditions. J. Econ. Entomol. 87, 1205-1212.

Smart, G.C., 1995. Entomopathogenic nematodes for the biological control of insects. J. Nematol. 27, 529-534.

StatSoft Inc., 2012. STATISTICA (data analysis software system), version 11. www.statsoft.com

Stokwe, N.F., 2009. Entomopathogenic nematodes: Characterisation of a new species, long-term storage and control of obscure mealybug, Pseudococcus viburni (Hemiptera: Pseudococcidae) under laboratory conditions. Thesis, Stellenbosch University, Private Bag X1, Matieland (Stellenbosch), South Africa.

Stokwe, N.F. \& Malan, A.P. 2010. Potential control of mealybugs using entomopathogenic nematodes. S. Afr. Fruit J. 7, 38-42. 
Stuart, R.J., Polavarapu, S., Lewis, E.E. \& Gaugler, R., 1997. Differential susceptibility of Dysmicoccus vaccinii (Homoptera: Pseudococcidae) to entomopathogenic nematodes (Rhabditida: Heterorhabditidae and Steinernematidae). Econ. Entomol. 90, 925-932.

Van Niekerk, S., 2012. The use of entomopathogenic nematodes to control citrus mealybug, Planococcus citri (Hemiptera: Pseudococcidae) on citrus in South Africa. Thesis, Department of Conservation Ecology and Entomology, Stellenbosch University, Private Bag X1, Matieland (Stellenbosch), South Africa.

Van Niekerk, S. \& Malan, A.P., 2012. Potential of South African entomopathogenic nematodes (Heterorhabditidae and Steinernematidae) for control of the citrus mealybug, Planococcus citri (Pseudococcidae). J. Invert. Pathol. 111, 166-176.

Walton, V.M., 2003. Development of an integrated pest management system for vine mealy bug, Planococcus ficus (Signoret), in vineyards in the Western Cape province, South Africa. Dissertation, Department of Conservation Ecology and Entomology, Stellenbosch University, Private Bag X1, Matieland (Stellenbosch), South Africa.
Walton, V.M. \& Pringle, K.L., 2004a. A survey of mealybugs and associated natural enemies in the vineyards in the Western Cape province, South Africa. S. Afr. J. Enol. Vitic. 25, 23-25.

Walton, V.M. \& Pringle, K.L., 2004b. Vine mealybug, Planococcus ficus (Signoret) (Hemiptera: Pseudococcidae), a key pest in South African vineyards. A review. S. Afr. J. Enol. Vitic. 25, 54-62.

White, G.F., 1927. A method for obtaining infective nematode larvae from cultures. Am. Assoc. Adv. Sci. 66, 302-303.

Yang, H., Jian, H., Zhang, S. \& Zhang, G., 1997. Quality of the entomopathogenic nematode Steinernema carpocapsae produced on different media. Biol. Control. 10, 193-198. 